\title{
Enhancing regulatory capability through a blended delivery learning and development framework: an empirical Australian example
}

Prue Oxford and Margaret C. Hardy*

Australian Pesticides and Veterinary Medicines Authority (APVMA), 102 Taylor Street, Armidale New South Wales 2350 Australia. * maggie.hardy@apvma.gov.au, +61 267702300.

\begin{abstract}
The Australian Pesticides and Veterinary Medicines Authority (APVMA) is a Commonwealth statutory authority responsible for the regulation of agricultural and veterinary chemical products in Australia.

Effective regulation is built on engaging with risk in alignment with the relevant legislation, and requires a combination of core public service, foundation, and technical skills, in addition to management and leadership capabilities. Mapping skills, competencies, and capabilities provided the scaffolding for the 2019-21 APVMA Learning and Development Framework (the Framework).
\end{abstract}

As the Framework was established to support blended delivery of distance and face-to-face learning activities, it was largely uninterrupted due to the COVID-19 pandemic as the public service increasingly pivoted to online learning.

\section{Keywords}

Learning and development; public service; regulation; remote learning; regulatory science

\section{Introduction}

The Australian Pesticides and Veterinary Medicines Authority (APVMA) is a statutory Commonwealth agency with responsibilities for the regulation of agricultural and veterinary (agvet) chemical products in alignment with the statutory criteria for safety, efficacy, and the protection of Australia's trade.

The agency has around 180 staff that work out of 2 locations: a main office in the regional city of Armidale, New South Wales (NSW) and an office in the national capital, Canberra, Australian Capital Territory (ACT).

As Australia's national regulator of agvet chemicals, the APVMA is made up of teams of highly qualified scientists and regulatory officers, supported by legal and administrative expertise and an enabling services corporate team.

From 2019-21, the agency reviewed best practice approaches to ensure continued support for the development of required competencies for government regulatory scientists.

Consideration of how best to design and deliver effective workplace training for regulatory officers across multiple office locations resulted in the 2019-21 APVMA Learning and Development Framework. This approach was developed as existing vocational, university-based, or professional education offerings were not well-placed to meet the agency's specific needs at the intersection of science, risk, and administrative law with a highly trained workforce.

The legislative framework prescribes much of how the agency operates to assess risk and perform its duties. A changing workforce is supported by policies and procedures that guide staff capabilities and capacity to ensure the APVMA continues to be a world-class regulator. 


\section{Challenges of relevant training within national qualification frameworks}

The delivery of formal workplace education and training in Australia that leads to recognised qualifications under the Australian Qualifications Framework (AQF) falls broadly to one or other of 2 provider systems which reflect historical distinctions between career pathways.

For careers like veterinary medicine, law, and accountancy, the pathway to practice is via a qualifying university degree (bachelor or higher), followed by registration with the relevant professional body. Ongoing education to maintain and update standards of practice is overseen by the professional bodies through continuing professional development (CPD).

For careers including skilled crafts or trades, formal vocational education and training (VET) is administered by the technical and further education (TAFE) sector in Australia. Courses and qualifications for specific fields, such as business or construction, are grouped into training packages, which in turn encompass qualifications at different levels of the AQF and specify precise content and competency requirements for each course. Providers must be accredited as registered training organizations (RTOs) to deliver courses and qualifications.

The highly prescriptive nature of training package structures presents challenges for organisations seeking to provide training for niche fields of work, particularly as the majority of APVMA regulatory staff hold a postgraduate qualification in a relevant field. In this context, the APVMA's workplace training needs effectively fell into a gap between the 2 systems of professional CPD and VET.

\section{Strategic context}

The Australian context for regulatory scientists is highly specialised, creating in turn an equally unique set of challenges around designing and delivering workplace learning and development programs that will meet the needs of the APVMA and its people into the future.

The Framework presented in this document was designed to ensure the APVMA has the necessary organisational capabilities and employee competencies to perform its legislative duties and enable high-quality, accurate, transparent, evidence-based, and independent regulatory decision-making.

The Framework is not a workforce plan, although it is designed to align with and complement workforce planning.

The APVMA Learning and Development Framework (Figure 1) represents the organisational and individual capabilities required to address the public service, organisational and regulatory aspects of the APVMA's work. It is distinct from CPD requirements for maintaining professional registrations and also from individual staff learning and development or performance plans, which are managed through separate processes within the agency.

In 2021, the Australian Government released the Regulator Performance Guide (RPG), which provides expectations for regulator performance and reporting. The principles are designed to:

- improve the accountability and transparency of regulator performance

- share best practice

- build regulator capability

- drive a culture of regulator excellence.

Principle 1, Continuous improvement and building trust, of the RPG suggests that regulators "actively share learnings and insights by participating in communities of practice, engaging with other regulators and stakeholders to reflect on best practice and lessons learned, including failures."

To ensure both office locations had access to joint training programs, the APVMA had pivoted to either partial or complete virtual delivery methods in 2019 for learning and development offerings, which meant the organisation was well-placed to continue delivery during COVID-19. 


\section{Learning and Development Framework}

The purpose of the Framework (Figure 1) is to map the capabilities needed by the APVMA to deliver on its corporate strategic objectives and to allow individuals and teams to engage with their roles.

The Framework draws on and aligns with broader public service guidance from across the Australian Public Service (APS) and relevant international standards, including:

- the APS Work Level Standards and Integrated Leadership System (ILS)

- the APS Leadership and Core Skills Strategy 2014-15

- the APS Academy

- APS regulatory capability development as part of the Deregulation Agenda

- International Organization for Standardization (ISO) standards for competency management (ISO:9001 and ISO:9004), process auditing (ISO:17021), and risk management (ISO:31000).

The Framework also provides a structural context for competencies, which in turn identifies the behaviours, skills, knowledge, abilities, and attributes that individually contribute to organisational capabilities. The competency framework (Figure 2) identifies the areas of knowledge, skills, and attributes that APVMA staff need. The Framework also illustrates the role of the APS Values in underpinning every aspect of the APVMA's work.

There are 5 key areas of competency (Table 1), and understanding their relationship to each other is a component of the framework (Figure 2). Each area of competency can be performed at any of 4 levels of proficiency, which align broadly to role levels (Table 2). An example of the competencies mapped to a position description is provided (Table 3).

For the purposes of the Framework:

Skill is the ability to perform a task successfully - i.e., what someone can do.

Competencies are observable evidence of an ability, skill, or qualification. They are behaviours made up of skills, knowledge, and on-the-job abilities. Competency is how a person gets a task done.

Capabilities, at the individual level, are the skills, competencies, and attributes that the individual can use and develop further. Capabilities are who can get a task done. At the organisational level, capabilities are made up of the competencies that exist within the organisation, and how it assembles them to meet its current and emerging priorities.

\section{Key competency areas of the Framework}

\section{Core APS}

Core APS competencies are the public-sector specific skills and knowledge that all APS employees need to work effectively within and across government entities. Effective understanding of APS ethical and legal frameworks, including the APS Values and APS Code of Conduct, as well as the structure and processes of government, is critical.

In a fast-paced, complex environment, public servants need the public sector-specific knowledge and skills that ensure they can:

- operate within the frameworks and values expected of the APS

- understand and support government processes

- collaborate within and across teams and/or agencies to solve problems

- apply effective public-sector professional skills within their area of expertise and work in the public interest to deliver value. 
The APVMA induction program includes self-directed and in-person training modules that cover off on essential aspects of core APS competencies. Induction and refresher training requirements for core APS competencies are documented in the Core Training Policy.

The Core Training Policy considers staff and organisational needs in relation to core APS competencies and will be reviewed routinely to ensure it remains fit for purpose.

\section{Foundation/professional}

Foundation and professional competencies are not necessarily APS-specific. They are the essential workplace skills and knowledge, such as time management and structuring work, project management, analytical and critical thinking, communication skills, and stakeholder management, that facilitate effective work within and across the agency and underpin management expertise.

\section{Technical and role-based}

Technical and role-based competencies are the regulatory science or other skills and knowledge (e.g., accounting, human resources, or legal expertise) that relate specifically to an individual role. Technical competencies may include not just the skills and knowledge required to do the day-to-day tasks of a role, but also preparation of briefing documents or responses to international requests for comment on that area of work.

The APVMA study encouragement scheme allows staff members to apply for financial support and/or study leave to undertake additional formal study for qualifications and/or professional certifications in relevant fields to enhance role-based competencies.

\section{Management}

Management competencies go beyond 'people skills,' they also include the competencies that allow staff with managerial responsibilities to:

- be accountable, responsive, and resilient in the management of their teams

- manage teams in line with APVMA performance management policies and processes

- build and maintain internal and external relationships

- ensure outcomes are achieved.

Specific areas of competency include decision-making, critical thinking, communication, negotiation, and advanced public service skills, such as the preparation of briefs for senior executives and ministerial offices, or papers for committees and international meetings.

\section{Leadership}

Leadership involves engaging people to make progress on challenges, innovate, collaborate, and move towards a new vision of the future. Effective leaders can anticipate future changes, which enables organisations and individuals to be ready to respond to and manage changes in a proactive rather than reactive way (APSC Leadership and Core Skills Strategy 2014-15).

The relative priority of each area of competency changes with role classifications. Developing and using core APS and foundation skills is a priority for general and entry level staff, experienced and senior staff draw more on technical and role-based and management skills, and leaders focus most of their time and attention on management and leadership-related responsibilities. 


\section{Future directions}

Staff enter the public service, from a wide range of industry, academic and professional backgrounds, and with an equally diverse set of skills, knowledge, and levels of proficiency in various areas. Staff early in their public service careers can be expected to approach tasks and issues differently from experienced senior staff, and the proficiency levels can help clarify expectations.

Staff and managers can use the competency framework, in combination with the APS Work Level Standards, as a tool for performance planning and development conversations to provide an overview of an individual's current level of proficiency in each area of competency and help identify strengths and areas for development.

The Framework illustrates the learning and development resources available to help employees build their skills and knowledge and progress in their career stream.

Learning and development evolves with the changing needs of staff. At the APVMA, this also considers legislative changes to which the agency must respond. This process relies on the principles of the RPG, including continual improvement and being risk-based and data driven.

\section{Foundation competencies}

A voluntary mentoring program continues to enhance the ongoing role-based training offered within teams and supports career progression throughout the public service.

A Leadership Development Program has been delivered to senior leaders at the EL2 level (Directors), which results in an Advanced Diploma of Leadership and Management. This program has been extended to emerging leaders at the EL1 (Assistant Director) and APS6 levels, while tools such as DiSC profiles have been useful for managers and their teams in starting conversations about ways of working and communicating most effectively.

The APVMA Framework shows examples of the specific knowledge areas that relate to each competency area and the learning and development resources and pathways available for staff to build and progress their competencies. This is set against a context of relevant APVMA-specific and APS guidance and frameworks.

\section{Acknowledgements}

The authors would like to acknowledge Prim Wyatt and Sara Maria, who were instrumental in the delivery of the Framework, and the staff of the APVMA, who provided valuable input as the Framework was implemented.

\section{Conflict of interest}

The authors declare no conflict of interest. 

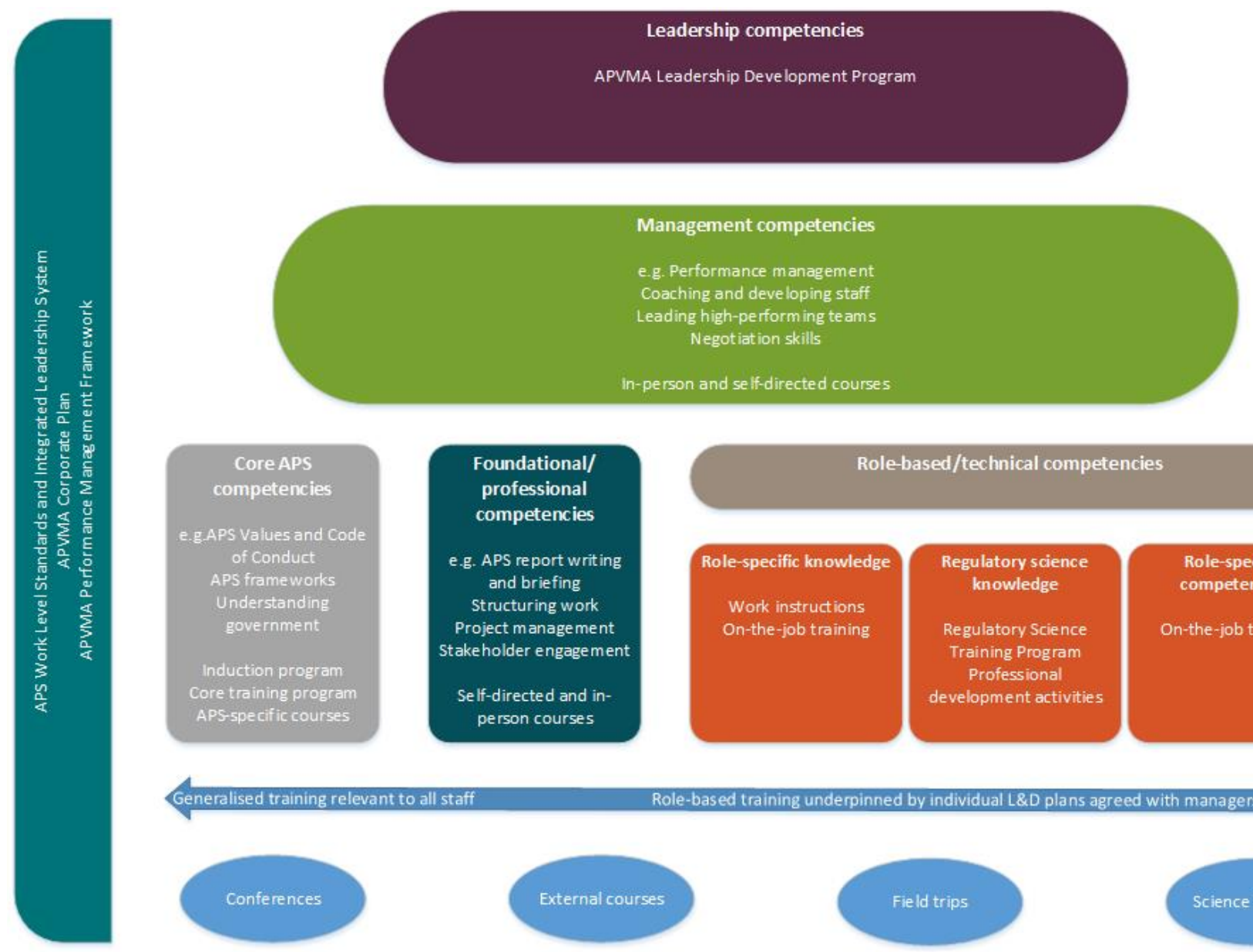

Role-based/technical competencies
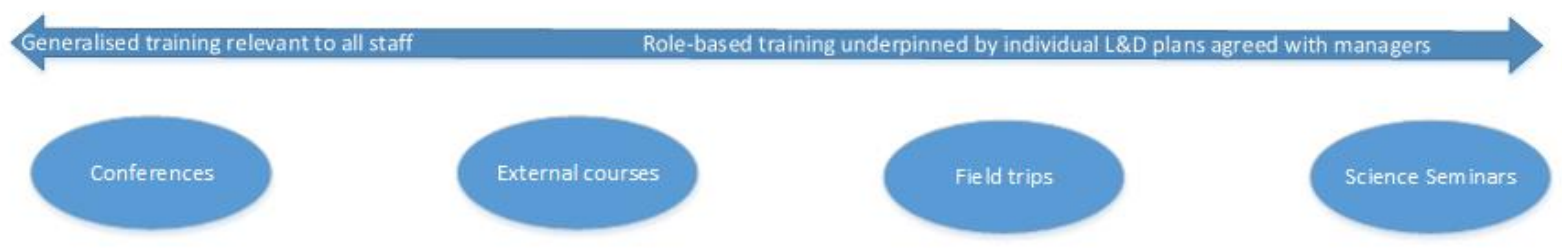

Figure 1. The Learning and Development Framework shows the internal and external resources and opportunities available for staff to build and enhance their competencies in each key area. 


\section{Leadership}

\section{Management}

\section{Core APS}
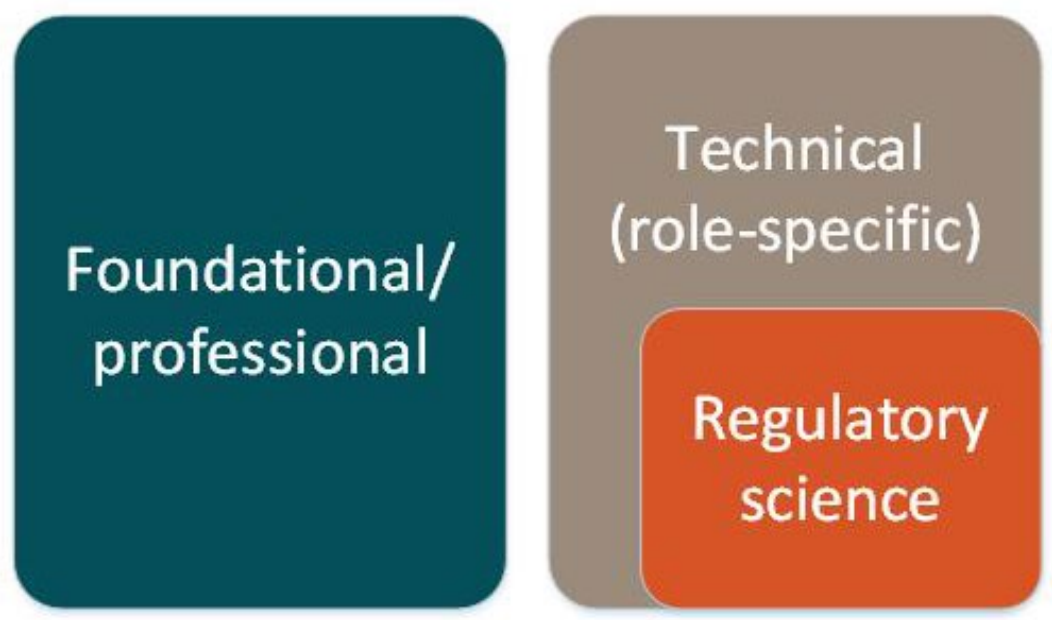

Figure 2. The key competency areas show how different skill types are related within the Framework. 
Table 1. Definitions of each of the key competency areas.

\begin{tabular}{|c|c|c|}
\hline Competency areas & Meaning & Specific examples \\
\hline Core APS & $\begin{array}{l}\text { Public sector-specific } \\
\text { knowledge and skills relevant to } \\
\text { all public service employees. }\end{array}$ & 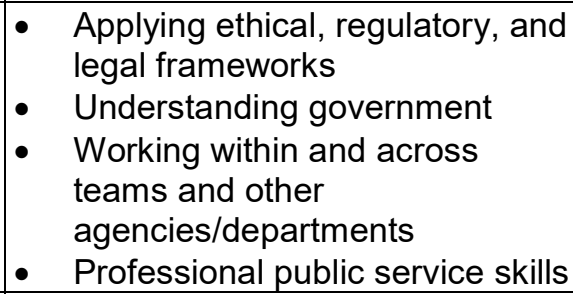 \\
\hline Foundation/professional & $\begin{array}{l}\text { Essential workplace skills } \\
\text { relevant to employees at all } \\
\text { levels. They underpin core skills } \\
\text { and management expertise and } \\
\text { are essential to operate } \\
\text { effectively in an organisation. }\end{array}$ & $\begin{array}{ll}\text { - } & \text { Structuring and managing work } \\
\text { - } & \text { Communicating effectively } \\
\text { - } & \text { Building relationships and } \\
\text { - } & \text { engagement } \\
& \text { Analytical thinking }\end{array}$ \\
\hline Technical/role-based & $\begin{array}{l}\text { Specific regulatory science or } \\
\text { other skills that relate directly to } \\
\text { a role (e.g., financial } \\
\text { accounting, legal, } \\
\text { communications, HR). }\end{array}$ & $\begin{array}{ll}\text { - } & \text { Depends on role } \\
\text { - } & \text { May include regulatory, } \\
\text { technical, or corporate } \\
\text { competencies }\end{array}$ \\
\hline Management & $\begin{array}{l}\text { Using formal authority and } \\
\text { processes to deliver outcomes } \\
\text { and use resources effectively. }\end{array}$ & $\begin{array}{ll}\text { - } & \text { Decision-making and judgement } \\
\text { - } & \text { Working with government } \\
\text { - } & \text { People and organisational } \\
& \text { development } \\
\text { - } & \text { Advanced professional public } \\
& \text { service skills }\end{array}$ \\
\hline Leadership & $\begin{array}{l}\text { Leading transformative change, } \\
\text { addressing complex policy and } \\
\text { delivery challenges, working } \\
\text { across boundaries, and } \\
\text { improving performance and } \\
\text { engagement. }\end{array}$ & $\begin{array}{ll}- & \text { Political nous } \\
\text { - } & \text { Strategic thinking } \\
\text { - } & \text { Leading change } \\
\text { - } & \text { Demonstrating leadership } \\
& \text { qualities }\end{array}$ \\
\hline
\end{tabular}


Table 2. Levels of proficiency for areas of key competency.

\begin{tabular}{|l|l|}
\hline Proficiency level & \begin{tabular}{l} 
Description \\
\hline Introductory
\end{tabular} \\
\hline Experienced & $\begin{array}{l}\text { General and entry level staff at the APS1 to } 5 \text { levels } \\
\text { Having a basic level of knowledge and being able to apply it } \\
\text { successfully to own work }\end{array}$ \\
\hline Senior & $\begin{array}{l}\text { Team leaders or managers at the APS6 and EL1 levels } \\
\text { Having comprehensive knowledge and being able to apply it } \\
\text { effectively and strategically to contribute to outcomes and } \\
\text { support less experienced staff }\end{array}$ \\
\hline Leader & $\begin{array}{l}\text { Senior managers at the EL2 level } \\
\text { Having an expert level of knowledge and being able to apply } \\
\text { that knowledge broadly and effectively across work areas to } \\
\text { implement strategy, lead groups and deliver results }\end{array}$ \\
\hline $\begin{array}{l}\text { Senior executive service (SES) level staff } \\
\text { Ability to apply an expert level of knowledge to provide } \\
\text { vision, set direction and motivate change }\end{array}$ \\
\hline
\end{tabular}


Table 3. Mapping competencies to roles.

\begin{tabular}{|c|c|c|}
\hline Position description examples* & Skill examples ${ }^{* *}$ & Knowledge \\
\hline $\begin{array}{l}\text { Providing high quality advice and customer } \\
\text { service to the executive, ministerial offices, } \\
\text { and other key stakeholders }\end{array}$ & $\begin{array}{ll}\text { - } & \text { Applying APS ethical and legal } \\
& \text { frameworks (C) } \\
\text { - } & \text { Understanding government (C) } \\
\text { - } & \text { Working within and across teams } \\
\text { - } & \text { and other agencies/departments (C) } \\
\text { - } & \text { Stakeholder management (F/P) } \\
\text { - } & \text { Critical thinking (F/P) } \\
\text { - } & \text { Specialist advice (R) }\end{array}$ & $\begin{array}{ll}\text { - } & \text { Legislative frameworks } \\
& \text { and political processes } \\
\text { - } & \text { Systems and tools } \\
\text { - } & \text { Briefing processes }\end{array}$ \\
\hline $\begin{array}{l}\text { Managing the day-to-day processing of } \\
\text { ministerial and parliamentary documents, } \\
\text { senior executive correspondence, Senate } \\
\text { Estimates briefs, and responses to requests } \\
\text { for information from Commonwealth, state, } \\
\text { and international agencies }\end{array}$ & $\begin{array}{ll}\text { - } & \text { Applying APS ethical and legal } \\
& \text { frameworks }(\mathrm{C}) \\
\text { - } & \text { Understanding government }(\mathrm{C}) \\
\text { - } & \text { Working within and across teams } \\
\text { - } & \text { Structuring agencies/departments }(\mathrm{C}) \\
\text { - } & \text { Communicating effectively (F/P) } \\
\text { - } & \text { Stakeholder management }(\mathrm{F} / \mathrm{P}) \\
\text { - } & \text { Writing senior executive and } \\
& \text { ministerial briefs }(\mathrm{M})\end{array}$ & $\begin{array}{l}\text { - } \quad \text { Legislative frameworks } \\
\text { and political processes } \\
\text { - } \quad \text { Systems and tools } \\
\text { - } \quad \text { Briefing processes and } \\
\text { standards }\end{array}$ \\
\hline $\begin{array}{l}\text { Editing and proofreading documents, } \\
\text { consulting with relevant line areas and } \\
\text { providing feedback on the quality of } \\
\text { documents }\end{array}$ & $\begin{array}{l}\text { - Working within/across teams (C) } \\
\text { - Communicating effectively (F/P) } \\
\text { - Stakeholder management (F/P) } \\
\text { - Editing and proofreading (F/P) }\end{array}$ & $\begin{array}{ll}\text { - } & \text { Editing and } \\
\text { proofreading } \\
\text { techniques } \\
\text { - } \\
\text { Australian government } \\
\text { style } \\
\text { - Systems and tools } \\
\text { - } \quad \begin{array}{l}\text { Document templates } \\
\text { and standards }\end{array}\end{array}$ \\
\hline $\begin{array}{l}\text { Managing and coordinating requests for input } \\
\text { received from external agencies }\end{array}$ & $\begin{array}{l}\text { - Structuring and managing work (F/P) } \\
\text { - Stakeholder engagement (F/P) }\end{array}$ & $\begin{array}{l}\text { - Systems and tools } \\
\text { - Document templates } \\
\text { and standards }\end{array}$ \\
\hline $\begin{array}{l}\text { Ensuring the quality and timeliness of all } \\
\text { inputs coordinated by the Unit }\end{array}$ & $\begin{array}{l}\text { - Working within/across teams (C) } \\
\text { - Structuring and managing work (F/P) } \\
\text { - Communicating effectively (F/P) }\end{array}$ & $\begin{array}{ll}\text { - } & \text { Legislative frameworks } \\
\text { and political processes } \\
\text { - } & \text { Australian government } \\
\text { style } \\
\text { - } \\
\text { - } & \text { Dystems and tools } \\
& \text { and standards } \\
\end{array}$ \\
\hline $\begin{array}{l}\text { Overseeing the secretariat function for the } \\
\text { internal committees }\end{array}$ & - Working within/across teams (C) & $\begin{array}{ll}\text { - } & \text { Australian government } \\
\text { style } \\
\text { - } \\
\text { - Systems and tools } \\
\text { Document templates } \\
\text { and standards }\end{array}$ \\
\hline $\begin{array}{l}\text { Assisting with educating and training staff on } \\
\text { the functions of the Unit }\end{array}$ & $\begin{array}{l}\text { - Working within/across teams (C) } \\
\text { - Communicating effectively (F/P) }\end{array}$ & $\begin{array}{l}\text { - } \quad \text { Legislative frameworks } \\
\text { and political processes } \\
\text { - Systems and tools } \\
\text { - } \quad \text { Briefing processes and } \\
\text { standards } \\
\text { - Document templates } \\
\text { and standards }\end{array}$ \\
\hline
\end{tabular}

\footnotetext{
${ }^{*}$ For an APS6 Senior International Coordination Officer. Not all duties, skills and knowledge are listed in this extract.
}

${ }^{* *}$ Key: Core APS (C); Foundation/professional (F/P); Technical/role-based (T/R); Management (M); Leadership (L) 